Published in final edited form as:

Semin Perinatol. 2013 April ; 37(2): 124-131. doi:10.1053/j.semperi.2013.01.009.

\title{
Pulmonary Hypertension in Bronchopulmonary Dysplasia
}

\author{
Sara K. Berkelhamer ${ }^{1}$, Karen K. Mestan ${ }^{1}$, and Robin H. Steinhorn² \\ ${ }^{1}$ Northwestern University's Feinberg School of Medicine \\ 2University of California Davis Medical Center and Children's Hospital
}

\begin{abstract}
Pulmonary hypertension $(\mathrm{PH})$ is a common complication of neonatal respiratory diseases including bronchopulmonary dysplasia (BPD), and recent studies have increased awareness that PH worsens the clinical course, morbidity and mortality of BPD. Recent evidence indicates that up to $18 \%$ of all extremely low birth weight infants will develop some degree of $\mathrm{PH}$ during their hospitalization, and the incidence rises to $25-40 \%$ of infants with established BPD. Risk factors are not yet well understood, but new evidence shows that fetal growth restriction is a significant predictor of PH. Echocardiography remains the primary method for evaluation for BPD-associated $\mathrm{PH}$, and the development of standardized screening timelines and techniques for identification of infants with BPD-associated PH remains an important ongoing topic of investigation. The use of pulmonary vasodilator medications such as nitric oxide, sildenafil, and others in the BPD population is steadily growing, but additional studies are needed regarding their long-term safety and efficacy.
\end{abstract}

\section{Background}

Bronchopulmonary dysplasia (BPD) is the most common chronic lung disease of infancy in the United States, and complicates the course of more than $30 \%$ of extremely preterm infants, resulting in 10,000 new cases annually in the United States. While prenatal steroids and surfactant have reduced rates of acute respiratory failure and improved survival, much more limited progress has been made in reducing rates of BPD. Multiple therapies such as non-invasive ventilation, vitamin $\mathrm{A}$, caffeine, superoxide dismutase, and inhaled nitric oxide have been tested to prevent BPD, but success has been inconsistent or modest.

The diagnosis of BPD increases the risk of long-term pulmonary morbidity, as well as cognitive, behavioral and social problems (1-4). Pulmonary hypertension $(\mathrm{PH})$ is a common complication of neonatal respiratory diseases including BPD, and recent studies have increased awareness that PH worsens the clinical course, morbidity and mortality of BPD.

\footnotetext{
(c) 2013 Elsevier Inc. All rights reserved.

Correspondence: Robin H. Steinhorn, MD, Professor and Chair, Department of Pediatrics, University of California Davis Medical Center, 2516 Stockton Blvd 3rd Floor, Sacramento, CA 95817, Ph: 916-734-5178, robin.steinhorn@ucdmc.ucdavis.edu. SKB, KKM and RHS have no conflicts to disclose.

Publisher's Disclaimer: This is a PDF file of an unedited manuscript that has been accepted for publication. As a service to our customers we are providing this early version of the manuscript. The manuscript will undergo copyediting, typesetting, and review of the resulting proof before it is published in its final citable form. Please note that during the production process errors may be discovered which could affect the content, and all legal disclaimers that apply to the journal pertain.
} 
Pediatric pulmonary hypertension centers now report caring for a growing number of children with BPD, which has emerged as the predominant population for many such programs (5). Retrospective studies of infants with BPD-associated PH have reported mortality rates ranging from 14-38\% (6-8). One series reported that mortality within 6 months of diagnosis was $35 \%$, and that for infants with severe BPD-associated PH, only $25 \%$ survived to $2-3$ years age (9).

With increasing survival of extremely premature infants, additional efforts are needed to reduce the burden and improve outcomes of BPD-associated PH. Despite increasing awareness of this association, studies have only recently begun to define the prevalence of $\mathrm{PH}$ in premature infants and to characterize the typical clinical course (10-12). Early retrospective studies of infants with BPD suggested that 25-37\% of babies with BPD develop associated $\mathrm{PH}$, but were hampered by inconsistent screening protocols (6-8). A recent large prospective single-site study was the first to perform routine echocardiography in all extremely low birth weight (ELBW) babies at a median age of 31 days of life to screen for the presence or absence of pulmonary hypertension (10). In this cohort, $6 \%$ of infants had evidence for PH during their 'early' screen, and by the time of discharge, serial echocardiography revealed that an additional $12 \%$ of the babies had developed PH prior to discharge (10). Babies with PH were more likely to be small for gestational age, and to require oxygen supplementation at 28 days and 36 weeks corrected gestation. PH persisted to discharge in most of the infants, and was associated with longer hospitalization times and higher mortality.

\section{Pathophysiology}

In contrast to the classic features of fibroproliferative BPD as originally described by Northway and others, lung disease in today's post-surfactant era is characterized by impaired alveolarization and compromised vasculogenesis that occurs when the preterm lung attempts to adapt to air breathing (13). Findings observed in both pre- and postsurfactant BPD include vascular remodeling (Figure 1), increased vascular tone and altered vasoreactivity $(14,15)$. These features, along with decreased vascular surface area, result in increased pulmonary vascular resistance (PVR) and pulmonary arterial hypertension, both of which can lead to right ventricular hypertrophy $(\mathrm{RVH})$ and dysfunction. In addition, animal models suggest that impaired angiogenesis during development disrupts alveolar development (16), and can produce marked PH later in life, with persistently reduced vessel density, pulmonary arterial remodeling, and RVH (17). Over time, reduced vascular growth limits vascular surface area and promotes high PVR, especially in response to high cardiac output at times of stress or exercise (18). In the most severe cases, cor pulmonale and right heart failure can result in death (19).

The complex cardiovascular pathology described above leads to a range of clinical presentations of disease. The pruned and small vascular bed which results from premature delivery and compromised lung growth likely contributes a "fixed", minimally modifiable component in $\mathrm{PH}$ while abnormal vascular tone and vasoreactivity will be more responsive to therapy (11). The degree to which therapy and/or ongoing lung growth can partially or completely reverse these components of disease remains a critically important question. 
The risk factors for PH include extremely low gestational age, small-for-gestational age birth weight, oligohydramnios, duration of mechanical ventilation and prolonged oxygen therapy $(7,8,10,20)$. While BPD and PH share many of the same risk factors, a growing body of evidence suggests that PH may be a separate disease with distinct pathophysiology. This is supported by clinical observations that despite having severe chronic lung injury, some BPD infants never develop PH, while other babies with relatively mild BPD do (8, 9, 12). The relatively "fixed" nature of $\mathrm{PH}$ is supported by the fetal origins hypothesis, in which it is believed that certain diseases that persist or arise later in life are due to an adverse intrauterine environment (20).

Compelling evidence for the fetal origins of PH is observed in the placental insufficiency sheep model of intrauterine growth restriction (21), in which Rozance and colleagues found significant pulmonary artery endothelial cell structural and functional changes in vitro that could account for the occurrence of long-standing PH in BPD infants. Therefore, fetal growth restriction secondary to chronic placental insufficiency appears to be an important mechanism of BPD-associated PTHN. Among clinical studies, the influence of the fetal environment on subsequent $\mathrm{PH}$ is perhaps most clearly seen in a small but wellcharacterized cohort of moderate-severe BPD infants (20). At 36 weeks adjusted age (2-3 months) $28 \%$ of these infants had $\mathrm{PH}$, and the association between degree of fetal growth restriction and $\mathrm{PH}$ was striking (Figure 2). Even mild fetal growth restriction (birth weight $<25^{\text {th }}$ percentile) was found to be a significant predictor of $\mathrm{PH}$, even after adjustment for multiple demographic, antenatal and postnatal factors known to influence the development of BPD.

Experimental models have further suggested that impaired signaling of the nitric oxide cyclic guanosine monophosphate (cGMP) signaling pathway may alter vascular responses and promote the development of both BPD and its associated PH. In sheep and primate models of prematurity, lung endothelial nitric oxide synthase (eNOS) expression is decreased and nitric oxide inhalation normalizes patterns of lung growth and vascularization $(22,23)$. Studies in preterm lambs show that deficient soluble guanylate cyclase activity may explain pathologic vascular responses to nitric oxide, and that elevated activity of the cGMP-specific phosphodiesterase (PDE5) may also disrupt normal cGMP levels and signaling (24). Since even brief periods of hyperoxia have been reported to increase PDE5 expression and activity (25-27), it seems possible that postnatal therapies may combine with risk factors to accentuate the disruptions in vascular growth and function.

\section{Screening and Diagnosis}

The development of standardized, clinically useful algorithms for identification of infants with BPD-associated PH remains an important topic of investigation. Symptoms of PH often overlap those of BPD itself including hypoxia, pulmonary instability, poor feeding and failure to thrive. Furthermore, the emergence of symptoms may indicate the disease has already progressed to a late, less reversible phase, supporting arguments for screening all infants at risk. Significant limitations of each screening modality add to the challenge of identifying who and when to screen. Evaluation of oxygen dependent infants at 36 weeks corrected gestational age has become common in many neonatal units. However, 
prospective screening of all ELBW infants at 28 days identified one third of patients much earlier, at a median age of 31 days of life (10). While earlier recognition of affected infants will lead to earlier initiation of targeted care, the impact on long-term outcomes remains unknown and one of the most important research questions.

\section{Electrocardiogram}

While electrocardiograms (ECGs) are inexpensive and easy to perform, ECG changes correlate very poorly with estimated pulmonary artery pressures by echocardiogram. RVH as determined by ECG proved only $69 \%$ sensitive for RVH detected by echocardiogram in a cohort of pediatric patients with congenital heart disease, and some patients will have significant PH despite normal ECG findings (28). As a result, ECG's cannot be recommended as a primary screening modality (18).

\section{Echocardiogram}

Echocardiography is non-invasive and widely available, and is currently the most commonly used screening modality for PH in infants with BPD. The tricuspid regurgitant (TR) jet is used to estimate systolic pulmonary artery pressure, and represents the most common and reliable method to evaluate for the presence and severity of PH. However, evaluation by echocardiography can be complicated by technician skill, a lack of standardized definitions, as well as the challenge of estimating pulmonary pressures when a tricuspid jet is not detected. A poor correlation between echocardiographic findings and right heart pressures by cardiac catheterization has been reported in both adult and pediatric populations $(29,30)$. Echocardiography in infants with BPD can be especially challenging due to the presence of lung hyperinflation and heart rotation, both of which impact the sensitivity of imaging and identification of the TR jet. Alternatives to measurement of the TR jet include assessment for flattening of interventricular septum (Figure 3), accelerated pulmonary regurgitation velocity, right atrial enlargement, or RVH and dilation. However, an important retrospective study reviewed the results of echocardiograms performed in close proximity to heart catheterization in 25 children under the age of 2 (30). The results showed that echocardiography correctly diagnosed the presence or absence of PH $79 \%$ of the time, but correctly determined the severity PH only $47 \%$ of the time. These results imply that in the absence of a quantifiable TR jet, the currently available indirect measurements are insufficient for the assessment of the degree of PH in infants with BPD.

\section{Cardiac catheterization}

Cardiac catheterization should be considered in all infants who have significant PH despite optimal management of their lung disease, who have unexplained or recurrent pulmonary edema, or before chronic pulmonary vasodilator therapy is begun. Cardiac catheterization will accomplish a number of important goals, including objective measurement of the severity of PH, assessment of right and left ventricular function, and evaluation for structural abnormalities of the heart or vasculature. Pulmonary venous stenosis is notoriously difficult to confirm by cardiac echo, but is strongly associated with prematurity and BPD (31). In one case series, the 2-year survival rate from diagnosis was $43 \%$, indicating that pulmonary venous stenosis is an important determinant of outcome and therapeutic approach. Similarly, evaluation of left atrial and pulmonary capillary wedge pressures will help identify infants 
with left ventricular dysfunction, which must be addressed prior to initiation of pulmonary vasodilators to avoid pulmonary edema and paradoxical deterioration. Cardiac catheterization also allows for acute vasoreactivity testing of responsiveness to oxygen and acute pulmonary vasodilators such as inhaled nitric oxide. The procedure is generally well tolerated in experienced hands, but is not without risk. One single center retrospective study of older pediatric $\mathrm{PH}$ patients (mean age 7.1 years) who underwent cardiac catheterization reported a $6 \%$ risk of resuscitation or death, although these rates are considerably higher than observed by others $(32,33)$.

\section{Biomarkers}

A rapid, non-invasive, easily performed diagnostic test would be valuable in the identification and management of BPD associated PH. Brain-type natriuretic peptide (BNP) is an endogenous peptide hormone secreted by the cardiac ventricles in response to increased wall stress, and has been proposed as a possible biomarker to determine the contribution of vascular disease and right ventricular strain. Levels of BNP and its prohormone, N-terminal pro-BNP (NT-proBNP) have been shown to correlate with mean pulmonary artery pressure, pulmonary vascular resistance and right atrial pressure in adults $(34,35)$. Several reports have indicated a similar positive correlation between BNP levels and echocardiographic findings of $\mathrm{PH}$ in pediatric populations (36-38), although it is not clear whether BNP levels can be used to directly assess the severity of PH. The paucity of age-specific reference data has also prevented broad adoption of this biomarker for pediatric PH, but fortunately recent studies have begun to fill this knowledge gap. Data from 690 infants and children identified that BNP levels peak at birth followed by a dramatic decline over the first days of life (39), and other studies have correlated BNP levels with acute neonatal PH or suggested that BNP and NT-proBNP levels may aid in the diagnosis and monitoring of infants with BPD associated PH (40). Currently, the test is most helpful when used to monitor trends in combination with other clinical and echocardiographic data.

Additional biomarkers that have been evaluated in adults may prove promising in pediatric populations. These could include endothelin-1, uric acid, troponin $\mathrm{T}$, exhaled nitric oxide, asymmetric dimethylarginine (ADMA) and cyclic GMP among others (41).

\section{Management}

While the presence of PH does not always correlate with severity of BPD, the approach to prevention and management of $\mathrm{PH}$ should include optimization of respiratory function and nutritional support to limit lung injury and facilitate lung growth. While support of respiratory function may include use of diuretics, inhaled steroids and/or bronchodilators, none of these have been shown to reduce the severity of BPD associated PH. Infants should also be evaluated for structural airway abnormalities such as vocal cord paralysis, subglottic stenosis, and tracheobronchomalacia. Gastroesophageal reflux is extremely common in preterm infants, and infants with BPD should be assessed for the presence of chronic aspiration. Aggressive management, including reducing oral intake, post-gastric feeding and/or Nissen fundoplication may need to be considered if severe reflux complicates lung disease. 
Chronic or intermittent hypoxia can lead to vasoconstriction and exacerbation of $\mathrm{PH}$. Exaggerated pulmonary vascular constriction in response to even mild hypoxia may be observed during cardiac catheterization in infants with BPD and can persist in older children $(14,15)$. Peripheral oxygen saturations should be monitored continuously by pulse oximetry, and levels maintained at $>92 \%$. On the other hand, while supplemental oxygen is often required to maintain adequate saturations, hyperoxia (saturation levels $>98 \%$ ) should be avoided. Exposure to high concentrations of oxygen compromises vascular and alveolar development (42), impairs nitric oxide (NO)-cGMP signaling through activation of the cGMP-specific phosphodiesterases $(25,26)$, and promotes pulmonary vascular dysfunction $(43,44)$.

\section{Pulmonary Vasodilators}

The general management strategies described above may prove insufficient for infants with severe or progressive vascular disease, prompting consideration of the use of pulmonary vasodilators. While experience with these medications in the BPD population is steadily growing, knowledge regarding their long-term safety and efficacy remains limited.

\section{Inhaled Nitric Oxide}

Nitric oxide (NO) is the biological signaling molecule synthesized by the enzyme nitric oxide synthase (NOS), and alterations in NO signaling are observed in conjunction with the vascular and lung injury characteristic of BPD (23). Three isoforms of NOS are present in the lung, although endothelial NOS is regarded as the most important regulator of NO production in the lung vasculature. NO stimulates guanylate cyclase activity in vascular smooth muscle cells, leading to production of cGMP, the critical second messenger that relaxes vascular smooth muscle through activation of cGMP-dependent protein kinase and cGMP-gated ion channels. Administration of inhaled NO (iNO) results in selective pulmonary vasodilation, but requires continuous administration due to its short half-life. While NO will not reverse the fixed component of BPD-associated PH, the reactive component does respond to iNO. Mourani et al showed that pulmonary pressures in patients with BPD improved to near-normal levels with acute exposure to iNO during cardiac catheterization, and that the effect was greater than the relaxation to oxygen alone (15). However, the benefit of prolonged treatment with iNO in BPD- associated PH has not been well studied. Chronic management with iNO is not yet practical in the outpatient setting due to the logistics of continuous treatment with an inhalational medication, but development of pulsed delivery systems may improve feasibility (45).

\section{Sildenafil}

Cyclic GMP is a central mediator of vascular contractility, so it is not surprising that its concentrations are tightly regulated to allow fine-tuning of vascular responses to oxygen, NO, and other stimuli. Phosphodiesterases are a large family of enzymes that hydrolyze and inactivate cGMP and cyclic adenosine monophosphate (cAMP), thus regulating their concentrations and effects. The cyclic GMP specific, or type 5 phosphodiesterase (PDE5) is especially highly expressed in the lung, and not only uses cGMP as a substrate but also contains a specific cGMP binding domain that serves to activate its catabolic activity. As the 
primary enzyme responsible for regulating cGMP, PDE5 is a crucial regulator of NOmediated vascular relaxation in the vascular cell (27).

Sildenafil is a selective PDE5 inhibitor approved by the Food and Drug Administration (FDA) for the treatment of pulmonary arterial hypertension in adults (46). Because of its longer half-life, sildenafil can be dosed at intervals through the day and administered orally. Studies have suggested that oral sildenafil reverses neonatal PH (47), and the STARTS-1 trial found short-term improvements after sixteen weeks of sildenafil therapy in older children with PH that was idiopathic or due to congenital heart disease (48). However, an extension study suggested that during chronic therapy of $>3$ years, children taking a high dose of sildenafil ( $>3 \mathrm{mg} / \mathrm{kg} / \mathrm{day}$ ) had a higher risk of death than children taking a low dose (48). As a result, the FDA recently issued an alert warning against sildenafil use in children ages 1-17 (49).

When reviewing these data, it is important to understand that the STARTS trial enrolled only children who were $>1$ year of age and without lung disease, so by design, it could not determine the potential efficacy or safety of sildenafil for infants with BPD (50). At least two case series of sildenafil treatment of infants with BPD-associated PH demonstrated improved pulmonary pressures without adverse side effects. The first study examined the effect of oral sildenafil in 25 infants and children ( $<2$ years of age) with PH due to chronic lung disease (mostly BPD). Most patients showed some improvement after a median treatment interval of 40 days, and the majority of infants were able to wean off iNO (51). However, in another case series, while sildenafil decreased pulmonary pressures, gas exchange was not improved, highlighting the multifactorial nature of BPD-associated PH (52). While sildenafil's ease of administration and these preliminary outcome data are encouraging, further studies will be needed to determine long-term outcomes in the BPD population.

\section{Prostacyclins}

Prostacycl in $\left(\mathrm{PGI}_{2}\right)$ is a metabolite of arachidonic acid that is endogenously produced by the vascular endothelium. The vascular effects of $\mathrm{PGI}_{2}$ are mediated through its binding to a membrane $\mathrm{PGI}_{2}$ receptor (IP) that activates adenylate cyclase and increases cAMP, which triggers smooth muscle cell relaxation through reducing intracellular calcium concentrations. PH in both neonates and older children is associated with decreased synthesis of prostacyclin, reduced expression of the IP receptor, and increased synthesis of the vasoconstrictor prostanoid thromboxane $\mathrm{A}_{2}(53,54)$.

Several prostanoid drug preparations are available for clinical use. Epoprostanol (prostacyclin) was one of the earliest therapeutic agents used for clinical treatment of $\mathrm{PH}$, and was approved by the FDA in 1995 for the treatment of severe chronic pulmonary arterial hypertension. Its short half-life necessitates continuous infusion and the associated risks of central line access. Epoprostenol has been shown to improve pulmonary hemodynamics, quality of life, exercise capacity, and survival in adults and children with idiopathic and secondary PH (55-60). These long-term improvements seem to occur even if acute vasodilation is not observed, suggesting that more indirect effects on platelet aggregation, inhibition of smooth muscle cell growth, or protection of right ventricular function may 
benefit patients with $\mathrm{PH}$ (61). The efficacy and safety of this therapy is still currently being explored in BPD associated PH (62), and the transition to outpatient use remains challenging. Adverse effects include systemic vasodilation, alterations in hepatic enzymes, inhibition of platelet aggregation, and side effects of jaw pain and diarrhea occur relatively frequently. Sudden interruption of the medication can lead to severe rebound PH (63).

Synthetic analogues of $\mathrm{PGI}_{2}$ have longer half-lives allowing for alternative modes of administration. Iloprost is a chemically stable prostacyclin analogue with a half-life of 20 30 minutes (64), and inhaled iloprost has been effective at reducing pulmonary pressures when given 6-9 times daily in pediatric patients, including some with BPD-associated PH (65). However, acute bronchoconstriction is a potentially serious adverse event that limits its utility in this patient population. Treprostinil, an even longer acting analogue of $\mathrm{PGI}_{2}$, can be administered as 4 inhaled doses daily or via subcutaneous injection. Subcutaneous treprostinil produces short-term improvements in exercise tolerance and hemodynamics in some adults with $\mathrm{PAH}$, but local site discomfort and induration can limit its tolerance. Subcutaneous treprostinil has been used to transition some children who were chronically stable on intravenous epoprostenol (66), and may improve clinical course in children as an add-on therapy (67). Preliminary effectiveness and safety studies of treprostinil have suggested it has an acceptable safety profile and clinical benefit in pediatric patients with $\mathrm{PH}$ (68), but additional studies in infants with BPD associated-PH are needed.

\section{Bosentan}

Endothelin-1 (ET-1) is a 21 amino acid protein that is a potent vasoconstrictor produced by endothelial cells in response to hypoxia. ET-1 promotes endothelial cell dysfunction, smooth muscle cell proliferation and remodeling, as well as inflammation and fibrosis (69). ET-1 binds to two receptor subtypes $\left(\mathrm{ET}_{\mathrm{A}}\right.$ and $\mathrm{ET}_{\mathrm{B}}$ ), and the binding of $\mathrm{ET}-1$ to the $\mathrm{ET}_{\mathrm{A}}$ receptor on smooth muscle cells produces vasoconstriction. Increased ET-1 production and altered ET receptor activity have been consistently reported in neonatal and adult animal models of $\mathrm{PH}$, and lung ET-1 expression and plasma ET levels were elevated in severe PAH in adults (70).

Bosentan is an orally active $\mathrm{ET}_{\mathrm{A}}$ and $\mathrm{ET}_{\mathrm{B}}$ receptor antagonist that has been used extensively in adult patients with $\mathrm{PH}$, often in combination with epoprostenol. Experience with bosentan in pediatric patients with $\mathrm{PH}$ has been favorable with improved outcomes $(71,72)$, and a specific pediatric formulation of bosentan was recently approved for use in children by the European authorities. Limited experience exists using bosentan for treatment of PH in infants with BPD has been published (73). Risks include dose-dependent hepatotoxicity, teratogenicity (mandating careful handling of the drug by caregivers) and possibly male infertility (74).

\section{Experimental Therapies}

\section{Stem Cell Therapies}

Recent animal and human studies suggest that damage or depletion of epithelial and/or vascular stem cells in the developing lung likely contributes to the pathogenesis of BPD (75). For instance, hyperoxia-induced BPD in neonatal rats is associated with decreased 
circulating and resident mesenchymal stem cells (MSC) (76). Administration of bone marrow derived mesenchymal stem cells or multipotent stromal cells prevents the compromised alveolar and vascular development observed in the murine hyperoxia-induced model of BPD $(76,77)$. Interestingly, this protection against lung injury occurs despite low rates of MSC engraftment in the lung. Recent studies identified that treatment with MSC conditioned media alone after hyperoxia reverses key features of disease, strongly implying a paracrine role for the protective effects. Use of stem cells or conditioned media containing their secreted factors may represent a novel therapeutic approach for BPD associated PH (78), but much still needs to be learned about their long-term effects and safety.

\section{Conclusion}

While numerous questions remain unanswered with respect to optimal screening protocols and clinical management of infants with BPD-associated PH, it is clear that the condition is relatively common in ELBW or growth-restricted premature infants in the modern postsurfactant era, and that the diagnosis carries a tremendous burden of morbidity and mortality. Great efforts are being made to better characterize the prevalence, clinical course and response to acute and chronic therapy. Experience with adult and pediatric PH may help identify candidate therapies, but the unique phenotype of BPD requires dedicated study if we are to identify appropriate target for this unique population.

\section{Acknowledgments}

Supported in part by HL54705 (RHS) and HL093302 (KKM)

\section{References}

1. Doyle LW, Anderson PJ. Long-term outcomes of bronchopulmonary dysplasia. Semin Fetal Neonatal Med. 2009 Dec; 14(6):391-5. [PubMed: 19766550]

2. Anderson PJ, Doyle LW. Neurodevelopmental outcome of bronchopulmonary dysplasia. Semin Perinatol. 2006 Aug; 30(4):227-32. [PubMed: 16860163]

3. Short EJ, Kirchner HL, Asaad GR, Fulton SE, Lewis BA, Klein N, et al. Developmental sequelae in preterm infants having a diagnosis of bronchopulmonary dysplasia: analysis using a severity-based classification system. Arch Pediatr Adolesc Med. 2007 Nov; 161(11):1082-7. [PubMed: 17984411]

4. Gough A, Spence D, Linden M, Halliday HL, McGarvey LP. General and respiratory health outcomes in adult survivors of bronchopulmonary dysplasia: a systematic review. Chest. 2012 Jun; 141(6):1554-67. [PubMed: 22116801]

5. Abman SH, Ivy DD. Recent progress in understanding pediatric pulmonary hypertension. Curr Opin Pediatr. 2011 Jun; 23(3):298-304. [PubMed: 21572384]

6. Slaughter JL, Pakrashi T, Jones DE, South AP, Shah TA. Echocardiographic detection of pulmonary hypertension in extremely low birth weight infants with bronchopulmonary dysplasia requiring prolonged positive pressure ventilation. J Perinatol. 2011 Oct; 31(10):635-40. [PubMed: 21311503]

7. An HS, Bae EJ, Kim GB, Kwon BS, Beak JS, Kim EK, et al. Pulmonary hypertension in preterm infants with bronchopulmonary dysplasia. Korean Circ J. 2010 Mar; 40(3):131-6. [PubMed: 20339498]

8. Kim DH, Kim HS, Choi CW, Kim EK, Kim BI, Choi JH. Risk factors for pulmonary artery hypertension in preterm infants with moderate or severe bronchopulmonary dysplasia. Neonatology. 2012; 101(1):40-6. [PubMed: 21791938] 
9. Khemani E, McElhinney DB, Rhein L, Andrade O, Lacro RV, Thomas KC, et al. Pulmonary artery hypertension in formerly premature infants with bronchopulmonary dysplasia: clinical features and outcomes in the surfactant era. Pediatrics. 2007 Dec; 120(6):1260-9. [PubMed: 18055675]

10. Bhat R, Salas AA, Foster C, Carlo WA, Ambalavanan N. Prospective analysis of pulmonary hypertension in extremely low birth weight infants. Pediatrics. 2012 Mar; 129(3):e682-9. [PubMed: 22311993]

11. Collaco JM, Romer LH, Stuart BD, Coulson JD, Everett AD, Lawson EE, et al. Frontiers in pulmonary hypertension in infants and children with bronchopulmonary dysplasia. Pediatr Pulmonol. 2012 Oct; 47(11):1042-53. [PubMed: 22777709]

12. Farquhar M, Fitzgerald DA. Pulmonary hypertension in chronic neonatal lung disease. Paediatr Respir Rev. 2010 Sep; 11(3):149-53. [PubMed: 20692628]

13. Jobe AH. The new bronchopulmonary dysplasia. Curr Opin Pediatr. 2011 Apr; 23(2):167-72. [PubMed: 21169836]

14. Abman SH, Wolfe RR, Accurso FJ, Koops BL, Bowman CM, Wiggins JW Jr. Pulmonary vascular response to oxygen in infants with severe bronchopulmonary dysplasia. Pediatrics. 1985 Jan; 75(1):80-4. [PubMed: 3838113]

15. Mourani PM, Ivy DD, Gao D, Abman SH. Pulmonary vascular effects of inhaled nitric oxide and oxygen tension in bronchopulmonary dysplasia. Am J Respir Crit Care Med. 2004 Nov 1; 170(9): 1006-13. [PubMed: 15184202]

16. Jakkula M, Le Cras TD, Gebb S, Hirth KP, Tuder RM, Voelkel NF, et al. Inhibition of angiogenesis decreases alveolarization in the developing rat lung. Am J Physiol Lung Cell Mol Physiol. 2000 Sep; 279(3):L600-7. [PubMed: 10956636]

17. Le Cras TD, Markham NE, Tuder RM, Voelkel NF, Abman SH. Treatment of newborn rats with a VEGF receptor inhibitor causes pulmonary hypertension and abnormal lung structure. Am J Physiol Lung Cell Mol Physiol. 2002 Sep; 283(3):L555-62. [PubMed: 12169575]

18. Mourani PM, Mullen M, Abman SH. Pulmonary hypertension in bronchopulmonary dysplasia. Progr Pediatr Cardiol. 2009; 27:43-8.

19. Hislop AA, Haworth SG. Pulmonary vascular damage and the development of cor pulmonale following hyaline membrane disease. Pediatr Pulmonol. 1990; 9(3):152-61. [PubMed: 2148977]

20. Check J, Gotteiner N, Liu X, Su E, Porta N, Steinhorn R, et al. Fetal growth restriction and pulmonary hypertension in premature infants with bronchopulmonary dysplasia. J Perinatol. In press.

21. Rozance PJ, Seedorf GJ, Brown A, Roe G, O’Meara MC, Gien J, et al. Intrauterine growth restriction decreases pulmonary alveolar and vessel growth and causes pulmonary artery endothelial cell dysfunction in vitro in fetal sheep. Am J Physiol Lung Cell Mol Physiol. 2011 Dec; 301(6):L860-71. [PubMed: 21873446]

22. MacRitchie AN, Albertine KH, Sun J, Lei PS, Jensen SC, Freestone AA, et al. Reduced endothelial nitric oxide synthase in lungs of chronically ventilated preterm lambs. Am J Physiol Lung Cell Mol Physiol. 2001; 281(4):L1011-20. [PubMed: 11557605]

23. Afshar S, Gibson LL, Yuhanna IS, Sherman TS, Kerecman JD, Grubb PH, et al. Pulmonary NO synthase expression is attenuated in a fetal baboon model of chronic lung disease. Am J Physiol Lung Cell Mol Physiol. 2003 May; 284(5):L749-58. [PubMed: 12676765]

24. Bland RD, Ling CY, Albertine KH, Carlton DP, MacRitchie AJ, Day RW, et al. Pulmonary vascular dysfunction in preterm lambs with chronic lung disease. Am J Physiol Lung Cell Mol Physiol. 2003 Jul; 285(1):L76-85. [PubMed: 12626336]

25. Farrow KN, Groh BS, Schumacker PT, Lakshminrusimha S, Czech L, Gugino SF, et al. Hyperoxia increases phosphodiesterase 5 expression and activity in ovine fetal pulmonary artery smooth muscle cells. Circ Res. 2008 Feb 1; 102(2):226-33. [PubMed: 17991881]

26. Farrow KN, Lee KJ, Perez M, Schriewer JM, Wedgwood S, Lakshminrusimha S, et al. Brief hyperoxia increases mitochondrial oxidation and increases phosphodiesterase 5 activity in fetal pulmonary artery smooth muscle cells. Antioxid Redox Signal. 2012 Aug 1; 17(3):460-70. [PubMed: 22229392]

27. Farrow KN, Steinhorn RH. Phosphodiesterases: emerging therapeutic targets for neonatal pulmonary hypertension. Handb Exp Pharmacol. 2011; (204):251-77. [PubMed: 21695644] 
28. Puchalski MD, Lozier JS, Bradley DJ, Minich LL, Tani LY. Electrocardiography in the diagnosis of right ventricular hypertrophy in children. Pediatrics. 2006 Sep; 118(3):1052-5. [PubMed: 16950997]

29. Arcasoy SM, Christie JD, Ferrari VA, Sutton MS, Zisman DA, Blumenthal NP, et al. Echocardiographic assessment of pulmonary hypertension in patients with advanced lung disease. Am J Respir Crit Care Med. 2003 Mar 1; 167(5):735-40. [PubMed: 12480614]

30. Mourani PM, Sontag MK, Younoszai A, Ivy DD, Abman SH. Clinical utility of echocardiography for the diagnosis and management of pulmonary vascular disease in young children with chronic lung disease. Pediatrics. 2008 Feb; 121(2):317-25. [PubMed: 18245423]

31. Drossner DM, Kim DW, Maher KO, Mahle WT. Pulmonary vein stenosis: prematurity and associated conditions. Pediatrics. 2008 Sep; 122(3):e656-61. [PubMed: 18762500]

32. Taylor CJ, Derrick G, McEwan A, Haworth SG, Sury MR. Risk of cardiac catheterization under anaesthesia in children with pulmonary hypertension. Br J Anaesth. 2007 May; 98(5):657-61. [PubMed: 17401143]

33. Hill KD, Lim DS, Everett AD, Ivy DD, Moore JD. Assessment of pulmonary hypertension in the pediatric catheterization laboratory: current insights from the Magic registry. Catheter Cardiovasc Interv. 2010 Nov 15; 76(6):865-73. [PubMed: 20549685]

34. Nagaya N, Nishikimi T, Okano Y, Uematsu M, Satoh T, Kyotani S, et al. Plasma brain natriuretic peptide levels increase in proportion to the extent of right ventricular dysfunction in pulmonary hypertension. J Am Coll Cardiol. 1998 Jan; 31(1):202-8. [PubMed: 9426041]

35. Mauritz GJ, Rizopoulos D, Groepenhoff H, Tiede H, Felix J, Eilers P, et al. Usefulness of serial Nterminal pro-B-type natriuretic peptide measurements for determining prognosis in patients with pulmonary arterial hypertension. Am J Cardiol. 2011 Dec 1; 108(11):1645-50. [PubMed: 21890089]

36. Vijlbrief DC, Benders MJ, Kemperman H, van Bel F, de Vries WB. B-type natriuretic peptide and rebound during treatment for persistent pulmonary hypertension. J Pediatr. 2012 Jan; 160(1):1115. e1. [PubMed: 21839472]

37. Vijlbrief DC, Benders MJ, Kemperman H, van Bel F, de Vries WB. Use of cardiac biomarkers in neonatology. Pediatr Res. 2012 Oct; 72(4):337-43. [PubMed: 22797141]

38. Reynolds EW, Ellington JG, Vranicar M, Bada HS. Brain-type natriuretic peptide in the diagnosis and management of persistent pulmonary hypertension of the newborn. Pediatrics. 2004; 114(5): 1297-304. [PubMed: 15520111]

39. Nir A, Lindinger A, Rauh M, Bar-Oz B, Laer S, Schwachtgen L, et al. NT-pro-B-type natriuretic peptide in infants and children: reference values based on combined data from four studies. Pediatr Cardiol. 2009 Jan; 30(1):3-8. [PubMed: 18600369]

40. Kim GB. Pulmonary hypertension in infants with bronchopulmonary dysplasia. Korean J Pediatr. 2010 Jun; 53(6):688-93. [PubMed: 21189939]

41. Warwick G, Thomas PS, Yates DH. Biomarkers in pulmonary hypertension. Eur Respir J. 2008 Aug; 32(2):503-12. [PubMed: 18669790]

42. Warner BB, Stuart LA, Papes RA, Wispe JR. Functional and pathological effects of prolonged hyperoxia in neonatal mice. Am J Physiol. 1998 Jul; 275(1 Pt 1):L110-7. [PubMed: 9688942]

43. Lakshminrusimha S, Swartz DD, Gugino SF, Ma CX, Wynn KA, Ryan RM, et al. Oxygen concentration and pulmonary hemodynamics in newborn lambs with pulmonary hypertension. Pediatr Res. 2009 Nov; 66(5):539-44. [PubMed: 19680165]

44. Lakshminrusimha S, Steinhorn RH, Wedgwood S, Savorgnan F, Nair J, Mathew B, et al. Pulmonary hemodynamics and vascular reactivity in asphyxiated term lambs resuscitated with 21 and 100\% oxygen. J Appl Physiol. 2011 Nov; 111(5):1441-7. [PubMed: 21799125]

45. Ivy DD, Parker D, Doran A, Kinsella JP, Abman SH. Acute hemodynamic effects and home therapy using a novel pulsed nasal nitric oxide delivery system in children and young adults with pulmonary hypertension. Am J Cardiol. 2003 Oct 1; 92(7):886-90. [PubMed: 14516902]

46. Rubin LJ, Badesch DB, Fleming TR, Galie N, Simonneau G, Ghofrani HA, et al. Long-Term Treatment with Sildenafil Citrate in Pulmonary Arterial Hypertension: SUPER-2. Chest. 2011 May 5. 
47. Baquero H, Soliz A, Neira F, Venegas ME, Sola A. Oral sildenafil in infants with persistent pulmonary hypertension of the newborn: a pilot randomized blinded study. Pediatrics. $2006 \mathrm{Apr}$; 117(4):1077-83. [PubMed: 16585301]

48. Barst RJ, Ivy DD, Gaitan G, Szatmari A, Rudzinski A, Garcia AE, et al. A randomized, doubleblind, placebo-controlled, dose-ranging study of oral sildenafil citrate in treatment-naive children with pulmonary arterial hypertension. Circulation. 2012 Jan 17; 125(2):324-34. [PubMed: 22128226]

49. U.S. Food and Drug Administration. FDA Drug Safety Communication: FDA recommends against use of Revatio in children with pulmonary hypertension. 2012. [updated 8.30.2012]; Available from: http://www.fda.gov/Drugs/DrugSafety

50. Abman SH, Kinsella JP, Rosenzweig EB, Krishnan U, Kulik T, Mullen M, et al. Implications of the FDA Warning Against the Use of Sildenafil for the Treatment of Pediatric Pulmonary Hypertension. Am J Respir Crit Care Med. 2012 Dec 6.

51. Mourani PM, Sontag MK, Ivy DD, Abman SH. Effects of long-term sildenafil treatment for pulmonary hypertension in infants with chronic lung disease. J Pediatr. 2009 Mar; 154(3):379-84. 84, e1-2. [PubMed: 18950791]

52. Farrow KN, Steinhorn RH. Sildenafil therapy for bronchopulmonary dysplasia: not quite yet. J Perinatol. 2012 Jan; 32(1):1-3. [PubMed: 22202953]

53. Christman BW, McPherson CD, Newman JH, King GA, Bernard GR, Groves BM, et al. An imbalance between the excretion of thromboxane and prostacyclin metabolites in pulmonary hypertension. N Engl J Med. 1992 Jul 9; 327(2):70-5. [PubMed: 1603138]

54. Lakshminrusimha S, Porta NF, Farrow KN, Chen B, Gugino SF, Kumar VH, et al. Milrinone enhances relaxation to prostacyclin and iloprost in pulmonary arteries isolated from lambs with persistent pulmonary hypertension of the newborn. Pediatr Crit Care Med. 2009 Jan; 10(1):10612. [PubMed: 19057444]

55. Rosenzweig EB, Kerstein D, Barst RJ. Long-term prostacyclin for pulmonary hypertension with associated congenital heart defects. Circulation. 1999 Apr 13; 99(14):1858-65. [PubMed: 10199883]

56. Barst RJ, Maislin G, Fishman AP. Vasodilator therapy for primary pulmonary hypertension in children. Circulation. 1999 Mar 9; 99(9):1197-208. [PubMed: 10069788]

57. Barst RJ, Rubin LJ, Long WA, McGoon MD, Rich S, Badesch DB, et al. A comparison of continuous intravenous epoprostenol (prostacyclin) with conventional therapy for primary pulmonary hypertension. The Primary Pulmonary Hypertension Study Group. N Engl J Med. 1996; 334(5):296-302. [PubMed: 8532025]

58. Barst RJ, Rubin LJ, McGoon MD, Caldwell EJ, Long WA, Levy PS. Survival in primary pulmonary hypertension with long-term continuous intravenous prostacyclin. Ann Intern Med. 1994 Sep 15; 121(6):409-15. [PubMed: 8053614]

59. Sitbon O, Humbert M, Nunes H, Parent F, Garcia G, Herve P, et al. Long-term intravenous epoprostenol infusion in primary pulmonary hypertension: prognostic factors and survival. J Am Coll Cardiol. 2002; 40(4):780-8. [PubMed: 12204511]

60. Yung D, Widlitz AC, Rosenzweig EB, Kerstein D, Maislin G, Barst RJ. Outcomes in children with idiopathic pulmonary arterial hypertension. Circulation. 2004 Aug 10; 110(6):660-5. [PubMed: 15289375]

61. D’Alonzo GE, Barst RJ, Ayres SM, Bergofsky EH, Brundage BH, Detre KM, et al. Survival in patients with primary pulmonary hypertension. Results from a national prospective registry. Ann Intern Med. 1991 Sep 1; 115(5):343-9. [PubMed: 1863023]

62. Zaidi AN, Dettorre MD, Ceneviva GD, Thomas NJ. Epoprostenol and home mechanical ventilation for pulmonary hypertension associated with chronic lung disease. Pediatr Pulmonol. 2005 Sep; 40(3):265-9. [PubMed: 15830393]

63. Doran AK, Ivy DD, Barst RJ, Hill N, Murali S, Benza RL. Guidelines for the prevention of central venous catheter-related blood stream infections with prostanoid therapy for pulmonary arterial hypertension. Int J Clin Pract Suppl. 2008 Jul.(160):5-9. [PubMed: 18638170]

64. Ewert R, Schaper C, Halank M, Glaser S, Opitz CF. Inhalative iloprost - pharmacology and clinical application. Expert Opin Pharmacother. 2009 Sep; 10(13):2195-207. [PubMed: 19663611] 
65. Ivy DD, Doran AK, Smith KJ, Mallory GB Jr, Beghetti M, Barst RJ, et al. Short- and long-term effects of inhaled iloprost therapy in children with pulmonary arterial hypertension. J Am Coll Cardiol. 2008 Jan 15; 51(2):161-9. [PubMed: 18191742]

66. Ivy DD, Claussen L, Doran A. Transition of stable pediatric patients with pulmonary arterial hypertension from intravenous epoprostenol to intravenous treprostinil. Am J Cardiol. 2007 Mar 1; 99(5):696-8. [PubMed: 17317374]

67. Levy M, Celermajer DS, Bourges-Petit E, Del Cerro MJ, Bajolle F, Bonnet D. Add-on therapy with subcutaneous treprostinil for refractory pediatric pulmonary hypertension. J Pediatr. 2011 Apr; 158(4):584-8. [PubMed: 21035821]

68. Krishnan U, Takatsuki S, Ivy DD, Kerstein J, Calderbank M, Coleman E, et al. Effectiveness and safety of inhaled treprostinil for the treatment of pulmonary arterial hypertension in children. Am J Cardiol. 2012 Dec 1; 110(11):1704-9. [PubMed: 22917554]

69. Abman SH. Role of endothelin receptor antagonists in the treatment of pulmonary arterial hypertension. Annu Rev Med. 2009; 60:13-23. [PubMed: 18764741]

70. Giaid A, Yanagisawa M, Lagleben D, Michel RP, Levy R, Shennib H, et al. Expression of endothelin-1 in the lungs of patients with pulmonary hypertension. N Engl J Med. 1993; 328:1732-39. [PubMed: 8497283]

71. Beghetti M. Current treatment options in children with pulmonary arterial hypertension and experiences with oral bosentan. Eur J Clin Invest. 2006 Sep; 36( Suppl 3):16-24. [PubMed: 16919006]

72. Maiya S, Hislop AA, Flynn Y, Haworth SG. Response to bosentan in children with pulmonary hypertension. Heart. 2006 May; 92(5):664-70. [PubMed: 16216850]

73. Rugolotto S, Errico G, Beghini R, Ilic S, Richelli C, Padovani EM. Weaning of epoprostenol in a small infant receiving concomitant bosentan for severe pulmonary arterial hypertension secondary to bronchopulmonary dysplasia. Minerva Pediatr. 2006 Oct; 58(5):491-4. [PubMed: 17008861]

74. Beghetti M, Hoeper MM, Kiely DG, Carlsen J, Schwierin B, Segal ES, et al. Safety experience with bosentan in 146 children 2-11 years old with pulmonary arterial hypertension: results from the European Postmarketing Surveillance program. Pediatr Res. 2008 Aug; 64(2):200-4. [PubMed: 18414142]

75. O'Reilly M, Thebaud B. Cell-based strategies to reconstitute lung function in infants with severe bronchopulmonary dysplasia. Clin Perinatol. 2012 Sep; 39(3):703-25. [PubMed: 22954277]

76. van Haaften T, Byrne R, Bonnet S, Rochefort GY, Akabutu J, Bouchentouf M, et al. Airway delivery of mesenchymal stem cells prevents arrested alveolar growth in neonatal lung injury in rats. Am J Respir Crit Care Med. 2009 Dec 1; 180(11):1131-42. [PubMed: 19713449]

77. Aslam M, Baveja R, Liang OD, Fernandez-Gonzalez A, Lee C, Mitsialis SA, et al. Bone marrow stromal cells attenuate lung injury in a murine model of neonatal chronic lung disease. Am J Respir Crit Care Med. 2009 Dec 1; 180(11):1122-30. [PubMed: 19713447]

78. Hansmann G, Fernandez-Gonzalez A, Aslam M, Vitali SH, Martin T, Mitsialis SA, et al. Mesenchymal stem cell-mediated reversal of bronchopulmonary dysplasia and associated pulmonary hypertension. Pulm Circ. 2012 Apr; 2(2):170-81. [PubMed: 22837858] 


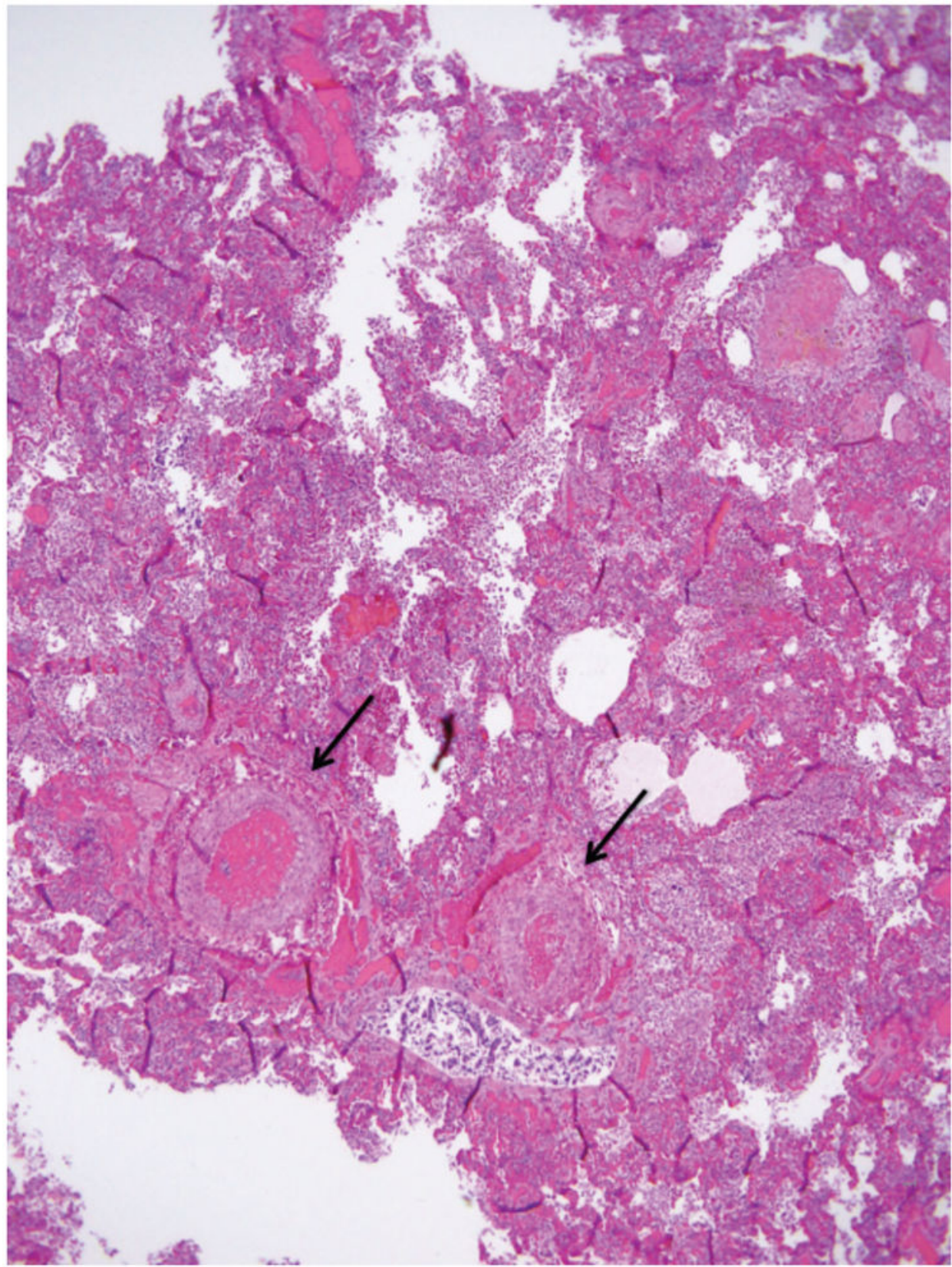

Figure 1.

Lung photomicrograph from a child with severe BPD and PH. Note the dramatically thickened pulmonary arteries (arrow), as well as findings of increased hemosiderin laden macrophages in the alveolar spaces and organizing pneumonia. 


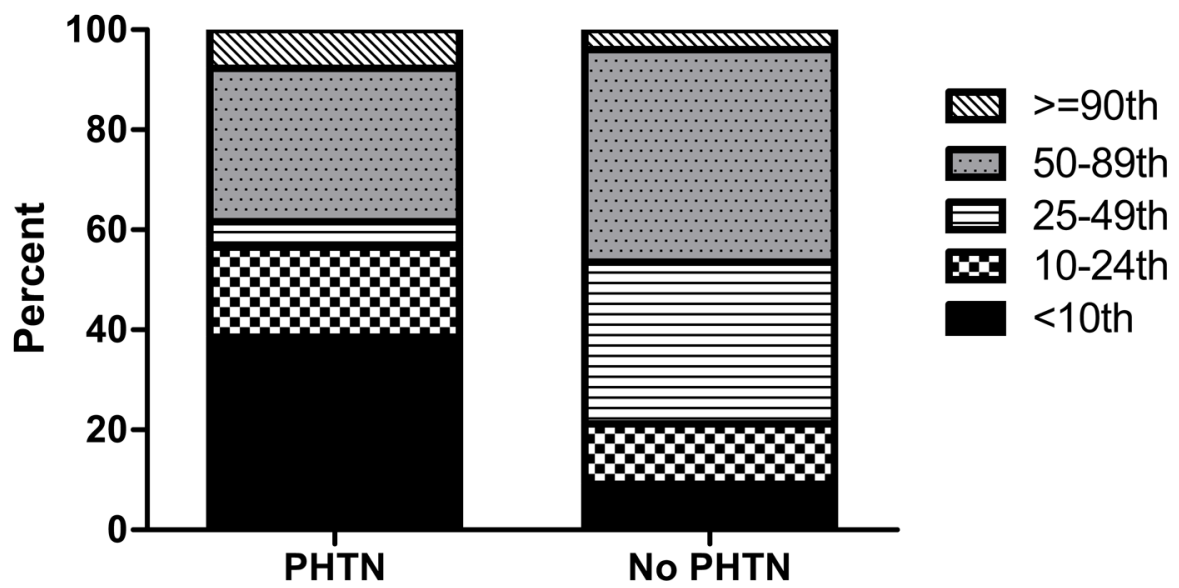

Figure 2.

The distribution of birth weight (BW) percentiles according to PH status. Bar graphs of five BW subgroups demonstrates that greater than one-half of infants with pulmonary hypertension had birth weights $<25^{\text {th }}$ percentile. PHTN: pulmonary hypertension. 

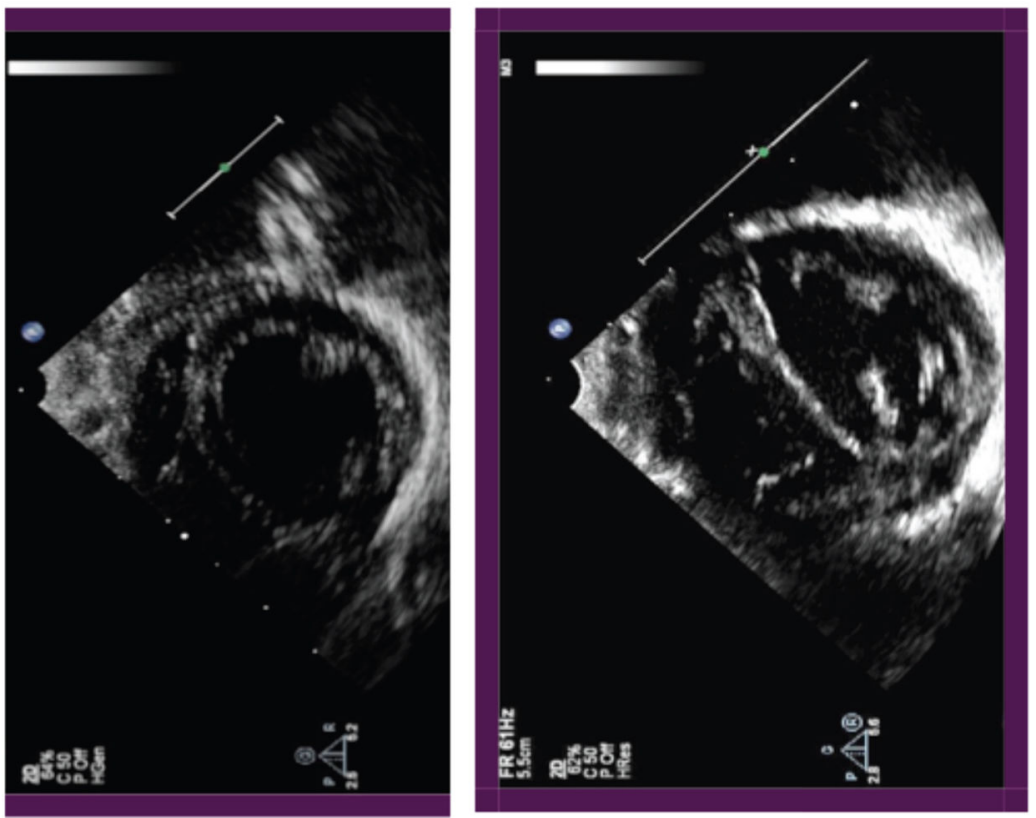

Figure 3.

Echocardiographic images depicting the septal flattening as seen in pulmonary hypertension. The upper image shows mild septal flattening, while the bottom image shows worse disease 


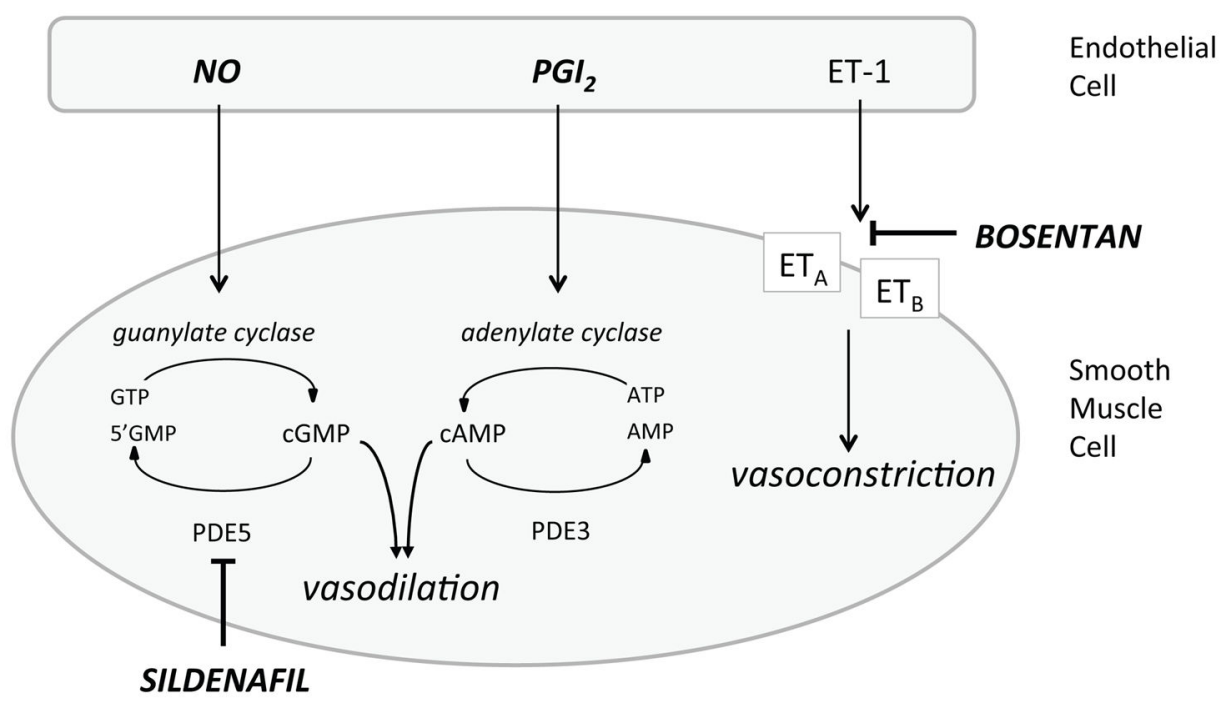

Figure 4.

Nitric oxide (NO), prostacyclin $\left(\mathrm{PGI}_{2}\right)$ and endothelin (ET)-1 signaling pathways in the regulation of pulmonary vascular tone. NO produced by endothelial cells stimulates soluble guanylate cyclase to increase intracellular cyclic GMP (cGMP). $\mathrm{PGI}_{2}$ produced by vascular endothelium stimulates adenylate cyclase to increase intracellular cyclic AMP (cAMP). Both cGMP and cAMP indirectly decrease free cytosolic calcium, resulting in smooth muscle relaxation. Sildenafil enhances vasodilation via inhibition phosphodiesterase 5 (PDE5) and the hydrolysis of cGMP. ET-1 produced by endothelial cells binds endothelin A (ETA) and endothelin B (ETB) receptors on smooth muscle cells. The ET-1 receptor antagonist Bosentan augments smooth muscle vasoconstriction by blocking ET-1 effects. 